Of similar significance is the demonstration that the administration of the concentrate to the minced tissue in vitro abolishes at once the difference between the avitaminous and the normal tissue.

H. E. Himwich and others (New Haven) contributed the results of a careful study of alcohol metabolism in dogs and men. Clear evidence has been obtained of a state of acidosis during the twenty-four hours following the oral administration of ethyl alcohol equivalent in amount to eight "double whiskies'. The bearing of this finding on the measurement of the respiratory quotients of human subjects needs no emphasis.

In the physiology of digestion, mention may be made of the accounts given by Soula and co-workers (Toulouse) on the relation between the blood sugar concentration and the secretion of the digestive juices, and of the studies on the effect of fat on gastric secretion and motility by Lim (Peiping) and Ivy and Zettelman (Chicago).

\title{
Co-operation in Electrical Standards
}

\begin{abstract}
A FACTOR which has greatly facilitated the rapid development of the electrical industry throughout the world is the close agreement which exists in practically all countries as to the units in terms of which the various electrical quantities are measured. The international adoption of the units of current and voltage, for example, has been a great help to international trade. It is a pity that a similar simplification has not been introduced into the various national units of length, mass and money. Luckily, the agreement in electrical matters is based upon measurements of the highest precision made in the leading laboratories of the world. The close co-operation which exists between the scientific workers and standardising institutions of all nations has made this possible. A brochure recently published from the National Physical Laboratory (H.M. Stationery Office, 2s.), containing Papers 2 and 3 of its "Collected Researches", vol. 24, is an admirable illustration of this co-operation. Part 2 gives the intercomparison of the capacitance (eapacity) and power factor of a mica capacitor (condenser). The tests were made by H. L. Curtis and C. Matilda Sparks of the Bureau of Standards and Dr. L. Hartshorn and N. F. Astbury of the National Physical Laboratory. Part 3 gives an international determination of the electromotive force of the normal Weston cell by P. Vigoureux of the National Physical Laboratory.

A mica condenser was transported on four occasions between the U.S. Bureau of Standards and the National Physical Laboratory. Seven sets of measurements were taken. During the first transportation a change occurred in the capacitance but
\end{abstract}

no subsequent changes were observed. The change in capacitance of a mica condenser with barometric height is normally about $0 \cdot 2$ parts in ten thousand. The differences in the barometric pressure due to the relative altitudes of the two laboratories and ordinary atmospheric variations probably produced a change of less than one part in ten thousand. When due allowance was made, the measurements carried out in the two countries agreed to about the hundredth part of one per cent. This is quite satisfactory seeing that the methods of measure. ment adopted by the two laboratories were quite different.

Mr. Vigoureux's paper gives an account of new determinations of the international units of current and voltage which were made in Berlin in the summer of 1931 by members of the staffs of the National Physical Laboratory, the U.S. Bureau of Standards, Washington, and the PhysikalischTechnische Reichsanstalt, Germany. The measurements were made by weighing the amount of silver deposited when the current flows through a solution of silver nitrate. In the experiments described the same current was passed in succession through the apparatus belonging to the three national repre. sentatives, who each made weighings of the silver deposited. The mean results of a number of experiments agreed to about one five-hundredth part of one per cent. Standard cells used at the various laboratories as standards of voltage were measured in terms of the current so determined, and certain small discrepancies which had been suspected between measurements made in the different countries were accounted for satisfactorily.

\section{Building Research*}

$\mathrm{M}^{\mathrm{A}}$ ANY developments in the work of the Research Station near Watford are described in the Report of the year's work of the Building Research Board recently published, and in spite of necessary economies evidence of useful activities for the improvement of materials and construction are no less apparent than in former years.

The cost of building is influenced by the regulations enforced in connexion with construction, and the modification of these regulations so far as London is concerned has called upon the work of the Station. At the request of the London County Council, a committee has been set up to review the present methods and regulations for the use of reinforced concrete and a considerable part has been taken in

- Department of Scientiflc and Industrial Research. Report of the Building Research Board, with the Report of the Director of Building Research, for the year 1931. Pp. ix +158. (London: H.M. Stationery Office, 1932). 3s. net.

No. 3288, Vol. 130] the work of the Steel Structures Research Committee, resulting in revised regulations by the Council on the subject of steel-framed buildings which should appreciably assist the steel industry and help to reduce building costs.

Tests on building materials are naturally a large item in the list of the researches undertaken by the Station and the increasing number of requests for such tests from outside has made some definite policy on this matter imperative. It has been decided to enlist the services of approved firms of testing engineers and institutions in carrying out this work under the supervision of the Station rather than incur large capital outlay, and this effort to reduce overlapping and utilise existing agencies is to be commended. The tests thus made will be to the approval of the Station, which will issue certificates upon them. 